\title{
PENYUSUNAN SKENARIO KEBIJAKAN UNTUK PENINGKATAN KINERJA PT. XYZ MENGGUNAKAN METODE DYNAMIC BALANCED SCORECARD
}

\author{
Aries Susanty ${ }^{*}$, Heri Suliantoro, Halida Dyandra \\ Departemen Teknik Industri, Fakultas Teknik, Universitas Diponegoro, \\ Jl. Prof. Soedarto, SH, Kampus Undip Tembalang, Semarang, Indonesia 50275 \\ (Received: January 4, 2019/ Accepted: March 14, 2019)
}

\begin{abstract}
Abstrak
PT.XYZ perlu untuk mengembangkan metode Balanced Scorecard (BSC) yang saat ini digunakannya menjadi System Dynamics-Based Balanced Scorecard (SD-BSC) karena keterbatasn dari metode BSC untuk memetakan hubungan timbal balik antara indikator-indikator yang digunakan dan ketercapaian target-target yang telah ditetapkan. Berdasarkan hal tersebut, studi ini memeliki beberapa tujuan. Pertama, menyusun causal loop diagram (CLD) dari indikator-indikator BSC yang telah dikembangkan oleh PT. XYZ; kedua, menyusun skenario kebijakan dan melakukan simulasi; serta ketiga, mengusulkan sejumlah rekomendasi kepada PT. XYZ atas dasar hasil simulasi tersebut. Studi ini menggunakan metode survai yang berupa wawancara dan penyebaran kuesioner untuk mengidentifikasi dan memvalidasi indiktor-indiktor yang nantinya berfungsi sebagai variabel dalam CLD. Studi ini juga menggunakan data sekunder berupa catatan perusahaan untuk mengetahui kondisi masing-masing indikator dan data-data lain yang dibutuhhkan. Hasil penelitian ini menunjukan bahwa indikator yang memberikan pengaruh terbesar pada pendapatan dan laba adalah jumlah produksi listrik sehingga indikator tersebut perlu diprioritaskan. Skenario terbaik dari hasil simulasi adalah skenario gabungan dengan memperoleh laba kumulatif sebesar Rp 5.875.297.558 dan pendapatan kumulatif sebesar Rp 40.959.313.558. Pencapaian laba dan pendapatan tersebut diperolah dari meningkatkan produktivitas operator sebesar 22,2\%. Peningkatan produktivitas operator dapat dilakukan dengan meningkatkan kepuasan karyawan sebesar 25,69\% dan meningkatkan jumlah karyawan mengikuti training menjadi 30 - 35 orang. Singkatnya, PT.XYZ perlu memberikan perhatian lebih pada Sumber Daya Manusia (SDM) untuk mengoptimalkan perolehan pendapatan dan laba.
\end{abstract}

Kata kunci: PT.XYZ; indikator; skenario; sistem dinamis; dynamic-based balanced scorecard

\begin{abstract}
PT. XYZ needs to develop a Balanced Scorecard (BSC) method which is currently used as a Dynamics-Based Balanced Scorecard (SD-BSC) because of the limitations of the BSC method to map the causal relationshi between indicators used and the achievement of targets has been established. Based on this condion, this study have several purposes. First, develop a causal loop diagram (CLD) of an indicator-indicator of BSC that has been developed by PT. XYZ; second, compile and stimulate several policy scenarios, and third, propose several recommendations to PT. XYZ based on the simulation results. This study uses survey methods in the form of interviews and questionnaires to identify and validate indictors which is used as variavle in CLD. This study also use secondary data in form of company record to know the condition of each indicator and the other data needed. The results of this study indicate the importance indicator which has the greatest influence on income and profits is the amount of electricity production. This indicator need to be prioritized. The best scenario from the simulation results is a combined scenario with a cumulative profit of Rp. 5,875,297,558 and cumulative income of Rp. 40,959,313,558. The achievement of profit and income is obtained from increasing operator productivity by $22.2 \%$. Increased operator productivity can be done by increasing employee satisfaction by $25.69 \%$ and increasing the number of employees participating in training to be 30-35 people. In short, PT. $X Y Z$ needs to pay more attention to Human Resources (HR) to optimize revenue and profit
\end{abstract}

Keywords: PT.XYZ; indicator; scenarios; system dynamic; dynamic-based balanced scorecard

\footnotetext{
*) Penulis Korespondensi.

E-mail: ariessusanty@yahoo.com
}

\section{Pendahuluan}

Menurut Simamora (2003), pengukuran kinerja merupakan alat manajemen untuk meningkatkan kualitas 
pengambilan keputusan dan akuntabilitas. Dalam konteks perusahaan, pengukuran kinerja terkait dengan serangkaian hasil yang dicapai dari proses bisnis dan hasil tersebut dicapai melalui pengorbanan berbagai macam sumber daya, termasuk sumber daya finansial (Moerdiyanto, 2010). Sebuah pengukuran kinerja sebaiknya melingkupi beberapa hal berikut ini (Tangen, 2004). Pengukuran kinerja harus melihat dari berbagai sudut pandang sehingga memiliki keseimbangan yang sesuai. Pengukuran kinerja sebaiknya terdiri dari ukuran kinerja yang spesifikasinya dapat dipahami. Pengukuran kinerja sebaiknya memiliki tujuan yang jelas dan terdefinisi, tidak ambigu, serta terdapat data yang dapat digunakan untuk mengukur.

Pengukuran kinerja merupakan salah satu masalah yang dihadapi oleh PT. XYZ yang merupakan Badan Usaha Milik Daerah (BUMD). PT. XYZ berlokasi di Bandung, Jawa Barat. Saat ini, bisnis utama PT. XYZ adalah pengelolan Sumber Daya Air yang berfokus kepada Sistem Penjualan Air Minum (SPAM) dan Pembangkit Listrik Minihidro (PLTM). Untuk mengetahui pencapaian kinerjanya dalam enam tahun yang akan datang, PT. XYZ telah menetapkan sejumlah target untuk dicapai dan indikator-indikator yang mendukung pencapaian sejumlah target tersebut. Secara keseluruhan, terdapat 19 indikator yang telah ditetapkan oleh PT. XYZ. Dalam hal ini, PT.XYZ telah menggunakan metode Balanced Scorecard (BSC) untuk memetakan keterkaitan antara sejumlah indikator dengan pencapaian target tertentu.

Metode BSC diperkenalkan untuk pertama kalinya oleh Kaplan dan Norton pada pertengahan tahun 1990. Menurut Kaplan dan Norton (2000), BSC memiliki empat perspektif yaitu perspektif pelanggan, perspektif proses bisnis internal, perspektif keuangan, dan perspektif pembelajaran dan pertumbuhan. BSC dianggap sebagai alat yang dapat mengatasi keterbatasan dari metode pengukuran kinerja secara tradisional karena BSC telah menambahkan ukuran-ukuran yang termasuk dalam perspektif non-finansial. Keunggulan pendekatan BSC dalam sistem perencanaan strategi adalah BSC mampu menghasilkan rencana strategi yang memiliki karakteristik komprehensif, koheren, terukur, dan seimbang (Mulyadi, 2001).

Namun demikian, hasil studi lebih lanjut mengindikasikan bahwa penetapan ke-19 indikator belum cukup menjamin PT.XYZ akan mampu mencapai target-target yang ditetapkan dalam enam tahun yang akan datang. Perusahaan perlu menyusun sejumlah skenario kebijakan untuk mendukung pencapaian targettarget yang telah ditetapkan dan skenario kebijakan ini harus dapat disimulasikan untuk melihat kemampuan setiap skenario dalam mencapai target yang ditetapkan. Dalam hal ini, perusahaan perlu mengembangkan metode BSC yang digunakannya saat ini menjadi System Dynamics-Based Balanced Scorecard (SD-BSC).
Pengembangan BSC menjadi SD-BSC tidak dapat dilepaskan dari kekurangan BSC yang hanya menggambarkan hubungan yang searah, mengabaikan adanya jeda waktu, kurang dinamis, dan kurang mencerminkan kepentingan pemangku kepentingan (Zhang, 2012). Konsep dari hubungan sebab akibat pada BSC tidak secara luas dijelaskan dan seringkali tidak jelas. Nørreklit (2000) mengkritik model BSC karena menyediakan arahan yang lemah mengenai hubungan sebab akibat. BSC juga memiliki kekurangan dalam mempertimbangkan jeda waktu antara sebab dan akibat. Akibatnya, lagging indicators dan leading indicators dicantumkan pada waktu yang sama, sebab dan akibat tidak dipisah waktunya, tidak adanya pertimbangan atau kesadaran bahwa suatu kebijakan dapat menimbulkan hasil jangka pendek yang berbeda dengan hasil jangka panjangnya (Barnabè, 2010).

Menurut Akkermans dan Oorschot (2002), keterbatasan metode BSC konvensional tersebut dapat diatasi dengan menggunakan pendekatan sistem dinamis. Akkermans dan Oorschot (2002) juga menjelaskan bahwa terdapat dua tahapan dalam pemodelan sistem dinamis untuk pengembangan BSC, yaitu tahap kualitatif dan kuantitaf. Tahap pertama, tahap kualitatif, mengumpulkan model mental dari manajemen untuk menghasilkan diagram hubungan timbal balik (causal loop diagram/ CLD) yang menggambarkan hubungan antara indikator dengan indikator dan antara indikator dengan pencapaian target-target yang telah ditetapkan. Tahap kedua, tahap kuantitatif, menerjemahkan CLD ke dalam model simulasi kuantitatif yang kemudian hasilnya didiskusikan dengan para manajer.

Berdasarkan keterbatasan dari metode BSC yang saat ini digunakan oleh perusahaan, secara ringkas, penelitian ini bertujuan untuk menyusun CLD dari indikator-indikator BSC yang telah dikembangkan oleh PT. XYZ, menyusun skenario kebijakan dan melakukan simulasi atas setiap skenario kebijakan, serta mengusulkan sejumlah rekomendasi kepada PT. XYZ atas dasar hasil simulasi tersebut. Studi ini mengganti perspektif pelanggan dalam BSC dengan perspektif pemangku kepentingan (stakeholder) dengan alasan berikut ini. Dalam menjalankan bisnisnya, PT XYZ tidak hanya melibatkan konsumen tetapi juga melibatkan sejumlah pemangku kepentingan lainnya (seperti masyarakat di sekitar perusahaan) dan konsumen merupakan bagian dari pemangku kepentingan tersebut. Sebagaimana dikatakan oleh Shaik dan Kader (2013), tujuan mengganti perspektif konsumen dengan pemangku kepentingan adalah agar BSC dapat mengakomodasi kepentingan dari berbagai pemangku kepentingan dan tidak hanya kepentingan dari konsumen.

\section{Bahan Dan Metode Desain Penelitian}

Studi ini termasuk dalam kelompok penelitian 
Causal-predictive adalah penelitian yang berusaha memprediksi akibat pada variabel dengan memanipulasi variabel yang lain (Cooper dan Schindler, 2014). Terdapat dua tahapan dalam studi ini. Pada tahap pertama, tahap kualitatif, dilakukan studi literatur dan studi lapangan untuk menentukan indikator-indikator yang kemudian akan divalidasi. Setelah mendapat indikator yang valid selanjutnya indikator-indikator tersebut dijadikan variabel untuk pengembangan model dalam bentuk CLD. Pada tahap kedua, tahap kuantitatif, dilakukan konstruksi komputer dari model CLD. Setelah konstruksi komputer terbentuk dan dapat disimulasikan, langkah selanjutnya adalah melakukan validasi berdasarkan struktur model dan validasi berdasarkan keluaran model. Validasi berdasarkan struktur model dilakukan dengan melihat apakah kontruksi program komputer sudah dapat melakukan simulasi dan menghasilkan keluaran tertentu. Adapun validasi berdasarkan keluaran model dilakukan dengan membandingkan antara data aktual dan data yang dihasilkan dari simulasi. Model dikatakan valid, jika tidak ada perbedaan yang signifikan antara data aktual dan data yang dihasilkan dari simulasi model; model dikatakan tidak valid jika terdapat perbedaan yang signifikan antara data aktual dan data yang dihasilkan dari simulasi model. Apabila model telah valid berdasarkan struktur model dan keluaran model, langkah selanjutnya adalah penyusunan sejumlah skenario atas strategi yang akan dilakukan. Selanjutnya, simulasi dilakukan atas untuk masing-masing skenario untuk kemudian dianalisis dan ditarik kesimpulan.

Studi ini menggunakan metode survei berupa wawancara, penyebaran kuesioner, dan observasi data sekunder. Dalam hal ini, wawancara dan penyebaran kuesioner yang pertama dilakukan untuk mengindentifikasi dan memvalidasi indikator-indikator yang nantinya merupakan variabel-variabel dari CLD. Wawancara dan penyebaran kuesioner ditujukan kepada perwakikan Divisi Keuangan, Divisi Operasi, dan Divisi SDM. Studi ini juga menggunakan metode survei yang berupa penyebaran kuesioner kedua untuk mengetahui tingkat kepuasan karyawan. Nantinya, nilai 'tingkat kepuasan karyawan' akan dibutuhkan dalam proses simulasi. Disamping melakukan wawancara dengan perwakikan dari Divisi Keuangan, Divisi Operasi, dan Divisi SDM, pengumpulan data dalam studi ini dilakukan pula dengan melakukan wawancara kepada sejumlah karyawan dalam rangka mendapatkan data historis dari sejumlah variabel. Pengumpulan data dengan melalui observasi pada sejumlah dokumen perusahaan dilakukan dalam rangka mendapatkan data historis untuk jumlah produksi listrik dan biaya-biaya yang dikeluarkan oleh perusahaan.

\section{Framework Pengolahan Data}

Penelitian ini menggunakan SD-BSC sebagai framework untuk pengolahan data. SD-BSC merupakan perpaduan antara sistem dinamis dan BSC. Dalam hal ini, sistem dinamis banyak dikembangkan dan digunakan untuk menyelesaikan sejumlah permasalan dalam bidang keteknikan, analisis strategi dan kebijakan, isu lingkungan, dan sebagainya (Forrester, 2007). Sistem dinamis didefinisikan sebagai sebuah prinsip dan teknik dari sistem kontrol umpan balik untuk memodelkan, menganalisis, dan memahami tingkah laku dinamis dari sitem yang kompleks (Barnabè, 2010). Sistem dinamis menggunakan konsep dasar seperti causal loop dan diagram stock and flows. Memodelkan sistem dinamis adalah sebuah alat untuk mengatasi kerumitan dan menggabungkan feedback loops dalam sistem dan hasilnya dari model sistem dinamis diperlihatkan menjadi bernilai dalam mengidentifikasi faktor-faktor yang mempengaruhi keluaran dari proses, program, dan keputusan (Sterman, 2000).

Memodelkan sebuah proses, yang merupakan dasar bagi sistem dinamis, tidak mudah. Tidak ada cara terbaik untuk membangun sebuah model yang suskes dan tidak ada prosedur optimal yang dapat menjamin kebergunaan model (Khakbaz dkk, 2014). Namun demikian, terdapat beberapa langkah yang dapat digunakan untuk membangun sebuah proses, yaitu (Barnabè, 2010), yaitu mengartikulasikan masalah yang perlu ditangani, memformulasi hipotesis dinamis atau teori mengenai penyebab dari masalah, membangun model simulasi untuk menguji hipotesis dinamis, menguji model, dan mendesain dan evaluasi kebijakan.

Keunggulan dari SD-BSC antara lain mampu memisahkan sebab dan akibat pada waktunya, melalui konsep time delays dan representasi matematis dalam model formal (Sterman, 2000). SD-BSC mampu mengidentifikasi, memformulasi, dan menganalisis struktur sistem lingkungan bisnis di bawah pengamatan, dalam ketentuan dari hubungan antara struktur dan tingkah laku (Davidsen, 2000). SD-BSC mampu menyaring ukuran kinerja dan parameter untuk memilih yang paling relevan pada setiap perspektif BSC (Akkermans dan Oorschot, 2002).

\section{Struktur Model}

Sesuai dengan teori BSC, struktur model yang digunakan dalam studi ini terdiri dari empat sub-sistem subsistem finansial, bisnis proses internal, pembelajaran dan pertumbuhan, serta subsistem pemangku kepentingan.

\section{Indikator}

Indikator-indikator untuk setiap perspektif dari BSC dapat dilihat pada Tabel 1. Sebagaimana telah dijelaskan sebelumnya, indikator-indikator ini diperoleh dari hasil studi literatur dan juga wawancara dengan sejumlah perwakilan dari PT. XYZ. 


\section{Hasil dan Pembahasan}

\section{a. Hasil Validasi Indikator}

Kuesioner untuk memvalidasi indikator menggunakan Likert. Kuesioner ini berisi 20 butir pertanyaan dengan skala likert 1 sampai 5. Skala ini menjelaskan (1) sangat tidak setuju, (2) tidak setuju, (3) ragu-ragu, (4) setuju, dan (5) sangat setuju. Hasil vailidasi dapat dilihat pada Tabel 1. Suatu indikator dinyatakan valid apabila memiliki nilai rata-rata lebih besar sama dengan 4. Berdasarkan hal ini tampak bahwa semua indikator yang diusulkan memiliki nilai rata-rata lebih besar sama dengan empat. Ini artinya, semua indikator yang diusulkan valid atau dapat diterima oleh perusahaan.

\section{b. Hasil Penyusunan Stock Flow Diagram}

Stock flow diagram (SFD) disusun berdasarkan pada struktur model dalam bentuk CLD yang digambarkan dalam Gambar 1. SFD disusun dengan bantuan Software Powersim. Secara grafis, SFD dapat dapat dilihat pada Gambar 2.

\section{c. Hasil Validasi Model}

Sebagaimana telah dijelaskan sebelumnya, tedapat dua jenis validasi yaitu validasi berdasarkan pada struktur model dan keluaran model. Validasi berdasarkan struktur model menunjukkan bahwa model telah valid karena kontruksi program komputer telah dapat melakukan simulasi dan menghasilkan keluaran tertentu. Adapun validasi berdasarkan keluaran model dilakukan dengan membandingkan besaran pendapatan dari data aktual dan besaran pendapatan dari simulasi selama tahun 2016 Alat uji yang digunakan untuk melakukan validasi keluaran model adalah Uji Wilcoxon Signed Rank. Uji Wilcoxon Signed Rank digunakan untuk mengetahui apakah terdapat perbedaan yang sinifikan antara dua jenis kelompok data yang dibandingkan, yaitu data aktual dan data hasil simulasi.

Hasil uji simulasi untuk besaran pendapatan dapat dilihat pada Tabel 2 berikut. Hasil Uji Wilcoxon Signed Rank menunjukkan nilai Asymp. Sig. (2 - tailed) sebesar 0,272 atau lebih besar dari 0,05. Kondisi ini mengindikasikan bahwa tidak ada perbedaan yang signifikan antara data pendapatan aktual selama tahun 2016 dan data pendapatan hasil simulasi selama tahun 2016. Hasil ini mengindikasikan bahwa model telah valid berdasarkan pada keluaran model.

Tabel 2. Hasil Uji Validasi Berdasarkan Keluaran dengan Menggunakan Uji Wilcoxon Signed Rank

\begin{tabular}{|c|c|c|c|}
\hline Tahun & Bulan & Aktual & Simulasi \\
\hline & Januari & Rp 910.378 .050 & $\mathrm{Rp} \quad 920.908 .972$ \\
\hline & Februari & Rp $\quad 840.283 .650$ & Rp 1.054.756.135 \\
\hline & Maret & Rp 1.034.322.500 & Rp 881.368 .026 \\
\hline & April & Rp 1.083.183.050 & $\begin{array}{ll}\mathrm{Rp} & 836.075 .904\end{array}$ \\
\hline & Mei & Rp 1.006.424.650 & Rp 1.047.725.530 \\
\hline & Juni & $\begin{array}{ll}\mathrm{Rp} & 834.846 .200\end{array}$ & Rp 1.079.001.934 \\
\hline & Juli & Rp 1.193.665.200 & Rp 904.677 .228 \\
\hline & Agustus & Rp 1.020.623.900 & Rp 912.135 .850 \\
\hline & September & Rp 1.167.628.000 & Rp 1.097.152.443 \\
\hline & Oktober & Rp 1.170.209.450 & $\begin{array}{ll}\mathrm{Rp} & 872.955 .024\end{array}$ \\
\hline & November & Rp 1.026.062.200 & Rp 1.134.580.119 \\
\hline & Desember & Rp 1.231.872.700 & Rp 1.089.845.206 \\
\hline \multicolumn{4}{|c|}{$\begin{array}{l}\text { Hasil Uji Wilcoxon Signed Rank: Asymp. Sig. }(2-\text { tailed })= \\
0,272>0,05\end{array}$} \\
\hline
\end{tabular}

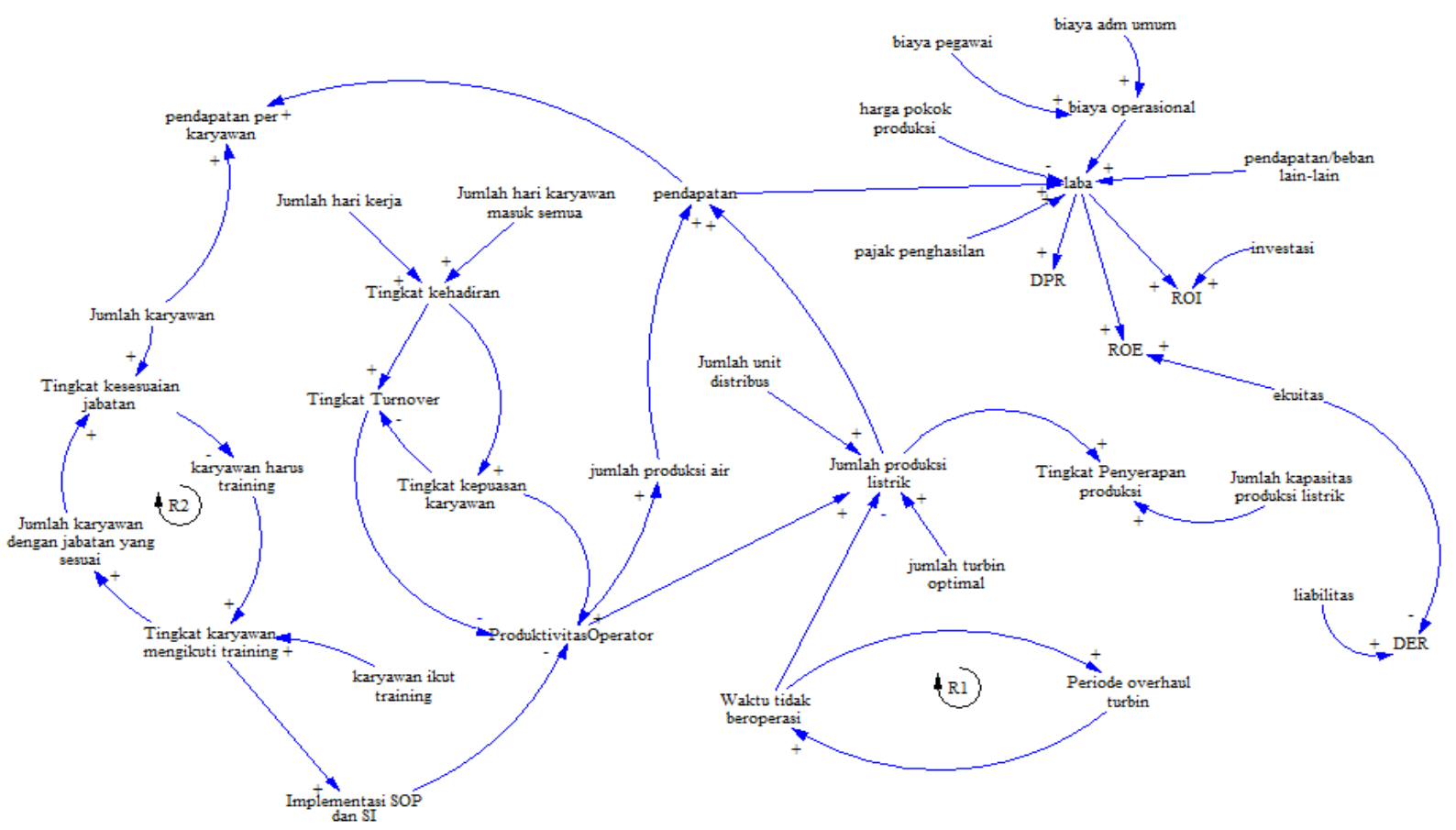

Gambar 1. Struktur Model dalam Bentuk CLD 


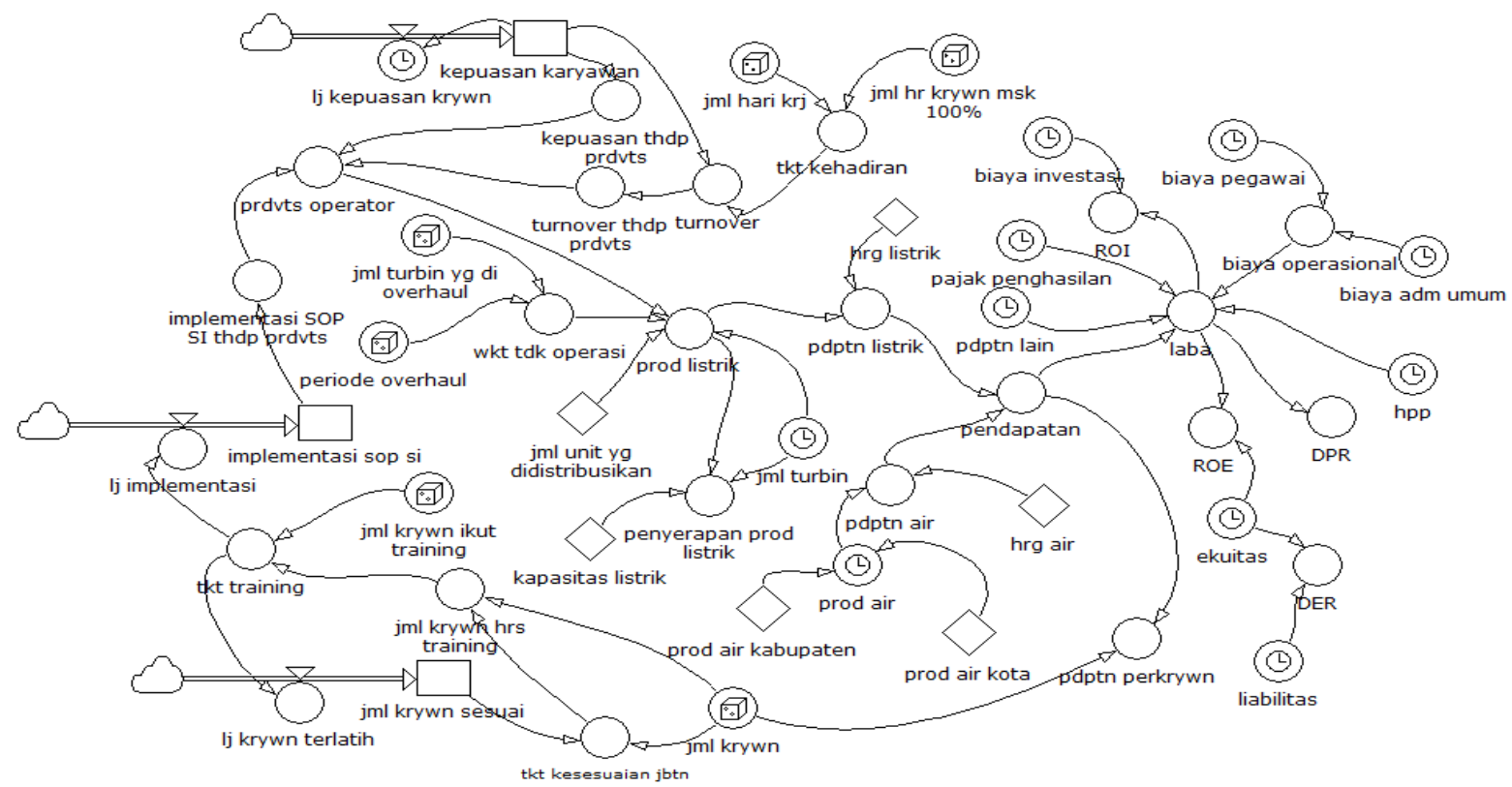

Gambar 2. Stock-Flow Diagram

Keterangan Gambar

\begin{tabular}{|c|c|c|c|c|c|}
\hline Nama Variabel & Rumus & Satuan & Nama Variabel & Rumus & Satuan \\
\hline jml hr krj & RANDOM(19;22) & Hari & $\begin{array}{l}\text { jml krywn hrs } \\
\text { training }\end{array}$ & (1-'tkt kesesuaian jbtn')*'jml krywn' & Jiwa \\
\hline $\begin{array}{l}\text { jml hr krywn msk } \\
100 \%\end{array}$ & RANDOM(16;21) & Hari & $\begin{array}{l}\text { tkt kesesuaian } \\
\text { jbtn }\end{array}$ & 'jml krywn sesuai'/'jml krywn' & $\%$ \\
\hline tkt kehadiran & 'hr krywn msk'/'jml hari krj' & $\%$ & jml krywn & RANDOM $(104 ; 110)$ & Jiwa \\
\hline lj kepuasan krywn & $\begin{array}{l}\text { STEP }\left(0^{*} \text { 'kepuasan }\right. \\
\text { karyawan';24) }\end{array}$ & $\%$ & prod air & $\begin{array}{l}\text { 0+STEP('prod air kab';26)+STEP('prod } \\
\text { air kot';28) }\end{array}$ & $m^{3}$ \\
\hline wkt tdk operasi & $\begin{array}{l}\text { ROUND('jml turbin yg di } \\
\text { overhaul'*'periode overhaul'*1) }\end{array}$ & Jam & penyerapan prod & $\begin{array}{l}\text { ('prod listrik'/'jml turbin')/'kapasitas } \\
\text { listrik' }\end{array}$ & $\%$ \\
\hline periode overhaul & ROUND(RANDOM(6;8)) & Jumlah & jml turbin & 4+STEP( $(0 ; 24)$ & Unit \\
\hline $\begin{array}{l}\text { kepuasan thdp } \\
\text { prdvts }\end{array}$ & $\begin{array}{l}\text { IF('kepuasan } \\
\text { karyawan'<1;'kepuasan } \\
\text { karyawan';1) }\end{array}$ & $\%$ & prod listrik & $\begin{array}{l}((239842,41-(7546,69 * ' w k t \text { tdk } \\
\text { operasi')+(292623,7*'prdvts operator')- } \\
(11475,4 * \text { 'jml unit yg } \\
\text { didistribusikan') }) * \text { 'jml turbin') }\end{array}$ & $\mathrm{kWh}$ \\
\hline prdvts operator & $\begin{array}{l}(0,7 *(0,752 * \text { 'kepuasan thdp } \\
\text { prdvts' })+(0,3 *(0,076+(0,24 * \text { tur } \\
\text { nover thdp } \\
\text { prdvts')+(1,01*'implementasi } \\
\text { SOP SI thdp prdvts') })))\end{array}$ & $\%$ & turnover & $\begin{array}{l}((0,904 *(1-' k e p u a s a n \\
\text { karyawan')+0,096*(1-'tkt kehadiran'))) }\end{array}$ & $\%$ \\
\hline $\begin{array}{l}\text { implementasi SOP } \\
\text { SI thdp prdvts }\end{array}$ & $\begin{array}{l}\text { IF('implementasi sop } \\
\text { si'<1;'implementasi sop si';1) }\end{array}$ & $\%$ & $\begin{array}{l}\text { jml turbin yg di } \\
\text { overhaul }\end{array}$ & ROUND(RANDOM $(1 ; 2))$ & unit \\
\hline lj implementasi & $\begin{array}{l}(0,131+(0,753 * \text { 'tkt } \\
\text { training'))*0,04 }\end{array}$ & $\%$ & $\begin{array}{l}\text { turnover thdp } \\
\text { prdvts }\end{array}$ & IF(turnover>0;turnover;0) & $\%$ \\
\hline tkt training & $\begin{array}{l}\text { 'jml krywn ikut training'/'jml } \\
\text { krywn hrs training' }\end{array}$ & $\%$ & pdptn listrik & 'prod listrik'*'hrg listrik' & $\mathrm{Rp}$ \\
\hline lj krywn terlatih & 'tkt training'* 0,583 \#) & $\%$ & pdptn air & 'prod air'*'hrg air' & $\mathrm{Rp}$ \\
\hline $\begin{array}{l}\text { jml krywn ikut } \\
\text { training }\end{array}$ & $\begin{array}{l}\text { RANDOM }(20+\text { STEP(10;24);25 } \\
+ \text { STEP }(10 ; 24))\end{array}$ & Jiwa & pendapatan & ('pdptn air'+'pdptn listrik') & $\mathrm{Rp}$ \\
\hline
\end{tabular}


Tabel 1. Validasi KPI

\begin{tabular}{|c|c|c|}
\hline Dimensi & Indikator & Rata-rata nila \\
\hline \multicolumn{3}{|l|}{ Perspektif finansial } \\
\hline \multirow{3}{*}{$\begin{array}{l}\text { Tingkat Pendapatan } \\
\text { (FP1) }\end{array}$} & Pendapatan (per bulan): pemasukan yang dimiliki perusahaaan dari aktivitas bisnis normal (FP11) & 4,33 \\
\hline & $\begin{array}{l}\text { ROI/ROE (per bulan): Ukuran atau indeks yang menunjukan seberapa besar laba didapat atas } \\
\text { investasi per tahun atau rasio keuangan yang menunjukkan besarnya laba bersih yang diperoleh dari } \\
\text { ekuitas perusahaan (FP12) }\end{array}$ & 4,33 \\
\hline & Laba Bersih (per bulan): kelebihan seluruh pendapatan atas seluruh biaya (FP13) & 4,33 \\
\hline $\begin{array}{l}\text { Pengendalian Biaya } \\
\text { (FP2) }\end{array}$ & Biaya operasional (per bulan): pengeluaran uang untuk melaksanakan kegiatan pokok (FP21) & 4,33 \\
\hline \multirow{2}{*}{$\begin{array}{l}\text { Perbaikan Struktur } \\
\text { Pendanaan (FP3) }\end{array}$} & $\begin{array}{l}\text { Dividend Payout Rato(per bulan):jumlah dividen yang dibayarkan kepada pemegang saham } \\
\text { dibandingkan dengan laba bersih perusahaan (FP31) }\end{array}$ & 4,33 \\
\hline & $\begin{array}{l}\text { Debt to Equity Ratio(per bulan): rasio hutang untuk mengukur tingkat pinjaman dari keuangan } \\
\text { perusahaan berdasarkan perbandingan total liabilitas dengan total ekuitas (FP32) }\end{array}$ & 4,00 \\
\hline \multicolumn{3}{|c|}{ Perspektif internal bisnis proses } \\
\hline \multirow{3}{*}{$\begin{array}{l}\text { Pengembangan Sistem } \\
\text { Operasi dan } \\
\text { Pemeliharaan yang } \\
\text { excellent (BP1) }\end{array}$} & $\begin{array}{l}\text { Produktivitas Operator (per bulan): daya guna operator dilihat dari kesalahan yang dilakukan di } 8 \\
\text { kegiatan operasi (BPI1) }\end{array}$ & 4,67 \\
\hline & $\begin{array}{l}\text { Waktu Tidak Beroperasi (per bulan): Waktu tidak bekerjanya turbin dalam memproduksi listrik } \\
\text { dikarenakan sedang mengalami perawatan (BP12) }\end{array}$ & 4,00 \\
\hline & $\begin{array}{l}\text { Tingkat Penyerapan Produksi (per bulan): Persentase banyaknya listrik yang diproduksi untuk } \\
\text { didistribusikan PLN (BPI13) }\end{array}$ & 4,00 \\
\hline $\begin{array}{l}\text { Perbaikan Sistem SOP } \\
\text { dan SI (BP2) }\end{array}$ & $\begin{array}{l}\text { Implementasi SOP dan Sistem Informasi (per bulan): SOP adalah kumpulan peraturan yang dibuat } \\
\text { untuk mempermudah pengerjaan tugas; SI adalah sistem yang dilakukan dalam menyediakan } \\
\text { informasi dalam rangka menjalankan operasional dan prosedur yang terorganisir (BPI21) }\end{array}$ & 4,67 \\
\hline $\begin{array}{l}\text { Penjadwalan } \\
\text { Pemeliharaan Secara } \\
\text { Teratur (BP3) }\end{array}$ & $\begin{array}{l}\text { Periode overhaul (per bulan): pembongkaran mesin untuk diperiksa dan diperbaiki jika diperlukan. } \\
\text { Waktu yang dibutuhkan turbin untuk diperiksa (BPI31) }\end{array}$ & 4,00 \\
\hline \multicolumn{3}{|c|}{ Perspektif pembelajaran dan pertumbuhan } \\
\hline $\begin{array}{l}\text { Tingkat Kompetensi } \\
\text { SDM (LG1) }\end{array}$ & $\begin{array}{l}\text { Tingkat karyawan mengikuti training (per bulan): Persentase karyawan mengikuti pelatihan untuk } \\
\text { meningkatkan kompetensi karyawan (LG11) }\end{array}$ & 4,00 \\
\hline $\begin{array}{l}\text { Tingkat Engagement } \\
\text { Karyawan (LG2) }\end{array}$ & $\begin{array}{l}\text { Turnover rate (per tahun): Tingkat karyawan meninggalkan perusahaan dan diganti karyawan baru } \\
\text { (LG21) }\end{array}$ & 5,00 \\
\hline \multirow{2}{*}{$\begin{array}{l}\text { Penerapan Budaya } \\
\text { "TIRTA" (LG3) }\end{array}$} & Tingkat kehadiran (per bulan): persentase kehadiran karyawan bekerja (LG31) & 4,33 \\
\hline & $\begin{array}{l}\text { Pendapatan per karyawan (per bulan): perbandingan antara pendapatan perusahaan karyawan } \\
\text { dengan jumlah karyawan saat ini (LG32) }\end{array}$ & 4,00 \\
\hline $\begin{array}{l}\text { Pengembangan } \\
\text { Organisasi (LG4) }\end{array}$ & $\begin{array}{l}\text { Tingkat kesesuaian jabatan dengan kompetensi (per bulan): persentase kesesuaian kompetensi } \\
\text { karyawan dengan jabatan yang didudukinya (LG41) }\end{array}$ & 4,00 \\
\hline \multicolumn{3}{|c|}{ Perpektif pemangku kepentingan*) } \\
\hline \multirow{3}{*}{$\begin{array}{l}\text { Kepuasan pelanggan } \\
\text { (SP1) }\end{array}$} & $\begin{array}{l}\text { Pemenuhan Kebutuhan Listrik yang Diminta oleh Pelanggan per bulan: banyaknya listrik yang } \\
\text { dihasilkan keempat turbin untuk memenuhi permintaan dari pelanggan (SP11) }\end{array}$ & 5,00 \\
\hline & $\begin{array}{l}\text { Pemenuhan Kebutuhan Air yang Diminta oleh Pelanggan per bulan): banyaknya air yang } \\
\text { dikelola untuk memenuhi permintaan dari pelanggan (SP12) }\end{array}$ & 5,00 \\
\hline & $\begin{array}{l}\text { Pemenuhan Kebutuhan Pelanggan atas Jumlah Unit yang Didistribusikan Listrik per bulan: } \\
\text { jumlah unit yang didistribusikan listrik sesuai dengan permintaan pelanggan (SP13) }\end{array}$ & 4,00 \\
\hline $\begin{array}{l}\text { Kepuasan Pekerja } \\
\text { (SP2) }\end{array}$ & $\begin{array}{l}\text { Tingkat Kepuasan Karyawan per tahun: tingkat kepuasan yang dirasakan karyawan dalam } \\
\text { menjalankan pekerjaannya (SP21) }\end{array}$ & 4,33 \\
\hline
\end{tabular}

\section{d. Hasil Perancangan Skenario Kebijakan}

Terdapat tujuh skenario kebijakan yang disusun, yaitu skenario model saat ini (model dasar), skenario produksi air, skenario penambahan jumlah turbin yang tersedia, skenario biaya, skenario peningkatan produktivitas operator, skenario penurunan produktivitas operator, dan skenario gabungan. Skenario ini disusun untuk melihat dampak kebijakan-kebijakan yang akan dilakukan perusahaan tahun 2018 terhadap indikator.
Kebijakan-kebijakan tersebut akan disimulasikan kemudian dianalisis sehingga dapat diketahui pengaruh dari kebijakan tersebut terhadap indikator. Secara rinci, kondisi dari ketujuh skenario kebijakan tersebut dapat dilihat pada Tabel 3.

Perbandingan hasil simulasi dari ketujuh skenario akan dilihat berdasarkan pada jumlah produksi listrik, jumlah produksi air, pendapatan dan laba yang dihasilkan. Secara grafis, perbandingan jumlah produksi 
listrik, jumlah produksi air, pendapatan dan laba yang dihasilkan dari setiap skenario dapat dilihat pada Gambar 3 sampai dengan Gambar 6. Gambar 3 menunjukkan bahwa produksi listrik baru meningkat secara signifikan pada skenario kebijakan jumlah turbin. Produksi listrik yang paling tinggi di akhir tahun simulasi adalah pada skenario gabungan, yaitu sebesar 34.510.816 kWh. Produksi listrik terbesar kedua ada pada skenario penambahan jumlah turbin yang tersedia, yaitu sebesar 31.223.958 kWh. Produksi listrik ketiga terbesar terdapat pada skenario peningkatan produtivitas operator. Skenario ini menghasilkan jumlah listrik sebesar 16.716.474,9 kWh. Skenario gabungan mendapat nilai tertinggi karena pada skenario gabungan menerapkan jumlah turbin yang meningkat dan produktivitas operator yang meningkat. Sebaliknya, produksi listrik mengalami penurunan pada skenario penurunan produktivitas operator. Pada skenario ini, produksi listrik turun menjadi menjadi 14.760.854,8 kWh. Namun demikian, apabila keempat skenario tersebut dibandingkan dengan model dasar, produksi listrik meningkat sebesar $122 \%$ pada skenario gabungan, produksi listrik meningkat sebesar $100 \%$ pada skenario penambahan jumlah turbin yang tersedia, dan produksi listrik meningkat sebesar sebesar $7,4 \%$ pada skenario peningkatan produktivitas operator, Produksi listrik menurun sebesar 5,2\% dibandingkan dengan model dasar pada skenario penurunan produktivitas operator.

Gambar 4 menunjukkan bahwa produksi air baru memiliki nilai pada Maret 2018 setelah sebelumnya hanya 0 . Hal ini hanya terjadi pada skenario produksi air dan skenario gabungan. Kedua skenario tersebut menerapkan kebijakan perusahaan untuk mulai memproduksi air bagi kabupaten dan kota. Kedua skenario ini pun memiliki nilai yang sama untuk Maret 2018 sampai dengan April 2018 sebesar 259.200m³ . Hal ini dikarenakan pada Maret 2018 sampai April 2018 perusahaan baru memulai produksi air hanya untuk kabupaten saja. Produksi air meningkat secara signifikan untuk kedua skenario pada Mei 2018. Produksi air pada Mei 2018 menjadi sebesar $777.600 \mathrm{~m}^{3}$ dan bertahan hingga Desember 2018. Peningkatan ini terjadi karena perusahaan sudah mulai memproduksi air untuk kota sebesar $518.400 \mathrm{~m}^{3}$.

Gambar 5 menunjukkan bahwa pendapatan mulai mengalami kenaikan pada Januari 2018. Skenario yang membuat pendapatan meningkat pada Januari 2018 adalah skenario penambahan jumlah turbin yang tersedia dan skenario gabungan. Pada akhir simulasi, pendapatan tertinggi diperoleh dari skenario gabungan sebesar Rp 40.959.313.558. Pendapatan tertinggi kedua diperoleh dari skenario penambahan jumlah turbin yang tersedia, yaitu sebesar Rp 26.540.365.025. Pendapatan tertinggi ketiga diperolah dari skenario produksi air, yaitu sebesar Rp 25.455.147.353. Pendapatan tertinggi keempat didapat dari skenario peningkatan produktivitas operator, yaitu sebesar Rp 14.209.003.670. Pada skenario penurunan produktivitas operator, pendapatan turun menjadi menjadi Rp 12.546.726.589. Jika dibandingkan dengan pendapatan pada model dasar, peningkatan meningkat sebesar $207 \%$ pada skenario gabungan, meningkat sebesar $190,7 \%$ pada skenario produksi air, meningkat sebesar $98,85 \%$ pada skenario penambahan jumlah turbin yang tersedia, meningkat sebesar $10 \%$ untuk skenario peningkatan produktivitas operator, dan menurun sebesar 5,99\% pada skenario penurunan produktivitas operator.

Selanjutnya, Gambar 6 menunjukkan bahwa perusahaan selalu mengalami kerugian sejak bulan Januari 2016 sampai dengan Bulan Desember 2017. Pada Bulan Januari 2018, perusahaan baru mendapatkan laba pada penerapan skenario kebijakan penambahan jumlah turbin yang tersedia. Selanjutnya, pada Bulan Maret 2018, penerapan skenario kebijakan produksi air mampu membuat perusahaan menghasilkan laba dan laba tersebut mengalami peningkatan pada Bulan Mei 2018. Skenario kebijakan peningkatan produktivitas operator maupun skenario kebijakan penurunan produktivitas operator belum mampu memberikan laba bagi perusahaan. Penerapan skenario kebijakan gabungan dapat membuat perusahaan menghasilkan laba pada Bulan Mei 2018. Pada akhir tahun simulasi, laba tertinggi diperoleh dari penerapan skenario kebijakan penambahan jumlah turbin yang tersedia, yaitu sebesar Rp 10.332.801.461. Perolehan laba tertinggi kedua diperoleh dari penerapan skenario produksi air, yaitu sebesar $\mathrm{Rp}$ 9.247.131.353. Perolehan laba tertinggi ketiga diperoleh dari penerapan skenario kebijakan gabungan, yaitu sebesar Rp 5.875.297.558. Jika dibandingkan dengan model dasar, skenario kebijakan peningkatan produktivitas operator mampu meningkatkan laba walaupun masih negatif, yaitu sebesar Rp (1.999.012.330). Skenario biaya menyebabkan terjadinya penurunan laba secara signifikan, yaitu menjadi sebesar Rp (-21.356.564). Perolehan laba terendah kedua terjadi pada skenario penurunan produktivitas operator. Pada skenario ini, laba turun menjadi Rp (-3.661.289.410,7).

Apabila dibandingkan dengan skenario model dasar, laba mengalami peningkatan sebesar $423 \%$ pada skenario penambahan jumlah turbin, mengalami peningkatan sebesar $401 \%$ pada skenario produksi air, mengalami peningkatan sebesar $305 \%$ pada skenario Gabungan, dan mengalami peningkatan sebesar 30,1\% pada skenario peningkatan produktivitas operator. Pada skenario biaya, laba mengalami penurunan sebesar $646 \%$ jika dibandingkan dengan model dasar dan pada skenario penurunan produksitas operator, laba mengalami penurunan sebesar $27,95 \%$ dibandingkan dengan model dasar. 
Tabel 3. Kondisi dari Ketujuh Skenario

\begin{tabular}{|c|c|c|c|c|}
\hline Skenario & Produksi Air & $\begin{array}{c}\text { Jml } \\
\text { Turbin }\end{array}$ & Biaya & Produktivitas Operator \\
\hline $\begin{array}{l}\text { Saat ini } \\
\text { (model dasar) }\end{array}$ & 0 & 4 & $\begin{array}{l}\text { - Harga pokok produksi Rp } 653.167 .000 \\
\text { - Biaya pegawai Rp 225.167.000 } \\
\text { - Biaya admumum Rp } 356.167 .000 \\
\text { - Biaya pendapatan lain Rp }(576.750 .000) \\
\text { - Biaya pajak penghasilan } \operatorname{Rp} 460.583 .000 \\
\text { - Biaya investasi Rp } 175.375 .000 .000 \\
\text { - Biaya ekuitas Rp 243.844.000.000 } \\
\text { - Biaya liabilitas Rp } 110.209 .000 .000\end{array}$ & $\begin{array}{l}\text { - Lj kepuasan krywn 0\% (nilai } \\
\text { awal kepuasan krywn 72\%) } \\
\text { - Jml krywn ikut training 20-25 } \\
\text { org }\end{array}$ \\
\hline Produksi air & $\begin{array}{ll}\text { - } & 259.200 \mathrm{~m}^{3} \\
& \text { (Kabupaten pada } \\
& \text { Maret 2018) } \\
- & 518.400 \mathrm{~m}^{3}(\text { Kota } \\
& \text { pada Mei 2018) }\end{array}$ & 4 & $\begin{array}{l}\text { - Harga pokok produksi Rp } 653.167 .000 \\
\text { - Biaya pegawai Rp 225.167.000 } \\
\text { - Biaya admumum Rp } 356.167 .000 \\
\text { - Biaya pendapatan lain Rp }(576.750 .000) \\
\text { - Biaya pajak penghasilan Rp } 460.583 .000 \\
\text { - Biaya investasi Rp 175.375.000.000 } \\
\text { - Biaya ekuitas Rp 243.844.000.000 } \\
\text { - Biaya liabilitas Rp 110.209.000.000 }\end{array}$ & $\begin{array}{l}\text { - Lj kepuasan krywn 0\% (nilai } \\
\text { awal kepuasan krywn } 72 \% \text { ) } \\
\text { - Jml krywn ikut training 20-25 } \\
\text { org }\end{array}$ \\
\hline $\begin{array}{l}\text { Penambahan } \\
\text { jumlah turbin }\end{array}$ & 0 & 8 & $\begin{array}{l}\text { - Harga pokok produksi Rp } 653.167 .000 \\
\text { - Biaya pegawai Rp 225.167.000 } \\
\text { - Biaya admumum Rp } 356.167 .000 \\
\text { - Biaya pendapatan lain Rp (576.750.000) } \\
\text { - Biaya pajak penghasilan Rp 460.583.000 } \\
\text { - } \text { Biaya investasi Rp 175.375.000.000 } \\
\text { - Biaya ekuitas Rp 243.844.000.000 } \\
\text { - Biaya liabilitas Rp 110.209.000.000 }\end{array}$ & $\begin{array}{l}\text { - Lj kepuasan krywn 0\% (nilai } \\
\text { awal kepuasan krywn 72\%) } \\
\text { - Jml krywn ikut training 20-25 } \\
\text { org }\end{array}$ \\
\hline Biaya & 0 & 4 & $\begin{array}{l}\text { - Harga pokok produksi Rp1. } 498.750 .000 \\
\text { - Biaya pegawai Rp } 333.834 .000 \\
\text { - Biaya admumumRp } 936.667 .000 \\
\text { - Biaya pendapatan lainRp }(66.917 .000) \\
\text { - Biaya pjk penghasilan Rp }(87.500 .000) \\
\text { - } \text { Biaya investasiRp } 134.000 .000 .000 \\
\text { - Biaya ekuitas Rp } 397.927 .000 .000 \\
\text { - Biaya liabilitas Rp 5.925.000.000 }\end{array}$ & $\begin{array}{l}\text { - Lj kepuasan krywn 0\% (nilai } \\
\text { awal kepuasan krywn } 72 \% \text { ) } \\
\text { - Jml krywn ikut training 20-25 } \\
\text { org }\end{array}$ \\
\hline $\begin{array}{l}\text { Peningkatan } \\
\text { produktivitas } \\
\text { operator }\end{array}$ & 0 & 4 & $\begin{array}{l}\text { - Harga pokok produksi Rp 653.167.000 } \\
\text { - Biaya pegawai Rp 225.167.000 } \\
\text { - Biaya admumum Rp } 356.167 .000 \\
\text { - Biaya pendapatan lain Rp }(576.750 .000) \\
\text { - Biaya pajak penghasilan Rp } 460.583 .000 \\
\text { - Biaya investasi Rp } 175.375 .000 .000 \\
\text { - Biaya ekuitas Rp 243.844.000.000 } \\
\text { - Biaya liabilitas Rp } 110.209 .000 .000\end{array}$ & $\begin{array}{l}\text { - Lj kepuasan krywn naik 5\% } \\
\text { (nilai awal kepuasan krywn } \\
72 \% \text { ) } \\
\text { - Jml krywn ikut training 30-35 } \\
\text { org }\end{array}$ \\
\hline $\begin{array}{l}\text { Penurunan } \\
\text { produktivitas } \\
\text { operator }\end{array}$ & 0 & 4 & $\begin{array}{l}\text { - Harga pokok produksi Rp } 653.167 .000 \\
\text { - Biaya pegawai Rp 225.167.000 } \\
\text { - Biaya admumum Rp } 356.167 .000 \\
\text { - Biaya pendapatan lain Rp (576.750.000) } \\
\text { - Biaya pajak penghasilan Rp 460.583.000 } \\
\text { - Biaya investasi Rp 175.375.000.000 } \\
\text { - Biaya ekuitas Rp 243.844.000.000 } \\
\text { - Biaya liabilitas Rp 110.209.000.000 }\end{array}$ & $\begin{array}{l}\text { - Lj kepuasan krywn turun 5\% } \\
\text { (nilai awal kepuasan krywn } \\
72 \% \text { ) } \\
\text { - Jml krywn ikut training 15-20 } \\
\text { org }\end{array}$ \\
\hline Gabungan & $\begin{array}{ll}\text { - } & 259.200 \mathrm{~m}^{3} \\
& \text { (Kabupaten pada } \\
& \text { Maret 2018) } \\
- & 518.400 \mathrm{~m}^{3}(\text { Kota } \\
& \text { pada Mei 2018) }\end{array}$ & 8 & $\begin{array}{l}\text { - Harga pokok produksi Rp1. } 498.750 .000 \\
\text { - Biaya pegawai Rp } 333.834 .000 \\
\text { - Biaya admumumRp } 936.667 .000 \\
\text { - Biaya pendapatan lainRp }(66.917 .000) \\
\text { - Biaya pjk penghasilan Rp }(87.500 .000) \\
\text { - Biaya investasiRp } 134.000 .000 .000 \\
\text { - Biaya ekuitas Rp } 397.927 .000 .000 \\
\text { - Biaya liabilitas Rp 5.925.000.000 }\end{array}$ & $\begin{array}{l}\text { - Lj kepuasan krywn naik 5\% } \\
\text { (nilai awal kepuasan krywn } \\
72 \% \text { ) } \\
\text { - Jml krywn ikut training 30-35 } \\
\text { org }\end{array}$ \\
\hline
\end{tabular}

\section{Kesimpulan}

Setelah dilakukan simulasi untuk tujuh buah skenario yang diusulkan, dapat disimpulkan bahwa skenario terbaik adalah skenario gabungan. Pada skenario gabungan, di akhir tahun simulasi, perusahaan akan memperoleh produksi listrik sebesar $34.510 .816 \mathrm{kWh}$, produksi air sebesar $6.739 .200 \mathrm{~m}^{3}$, pendapatan sebesar $\mathrm{Rp}$ 40.959.313.558, dan laba sebesar Rp 5.875.297.558. 
Nilai keempat indikator tersebut sudah mengalami peningkatan dibandingkan dengan skenario model dasar. Dalam hal ini, pencapaian laba sebesar Rp 5.875.297.558 pada akhir tahun simulasi perlu disertai dengan kemampuan perusahaan untuk meningkatkan pendapatan sebesar 207\%, yang berasal peningkatan produksi listrik dan produksi air. Produksi air harus sudah mulai beroperasi dan dapat memproduksi air bagi kabupaten sebesar $259.200 \mathrm{~m}^{3}$ dan bagi kota sebesar $518.400 \mathrm{~m}^{3}$ sehingga total produksi air mencapai $777.600 \mathrm{~m}^{3}$.

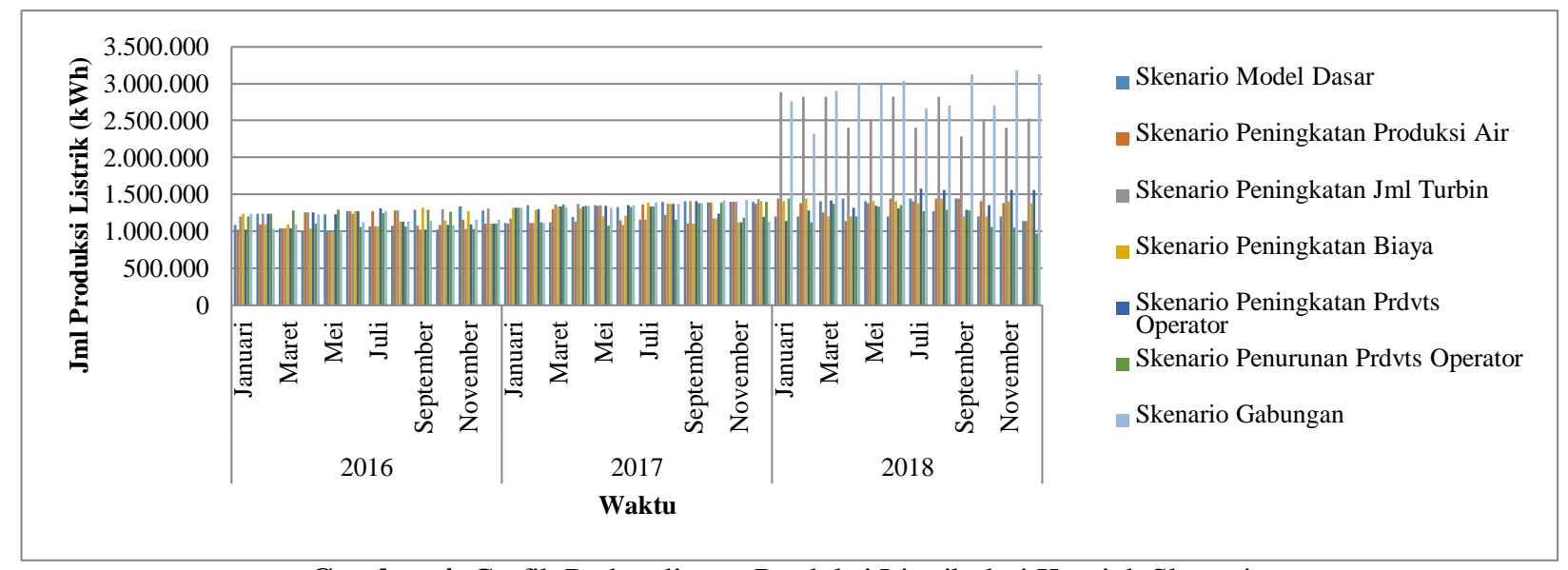

Gambar 4. Grafik Perbandingan Produksi Listrik dari Ketujuh Skenario

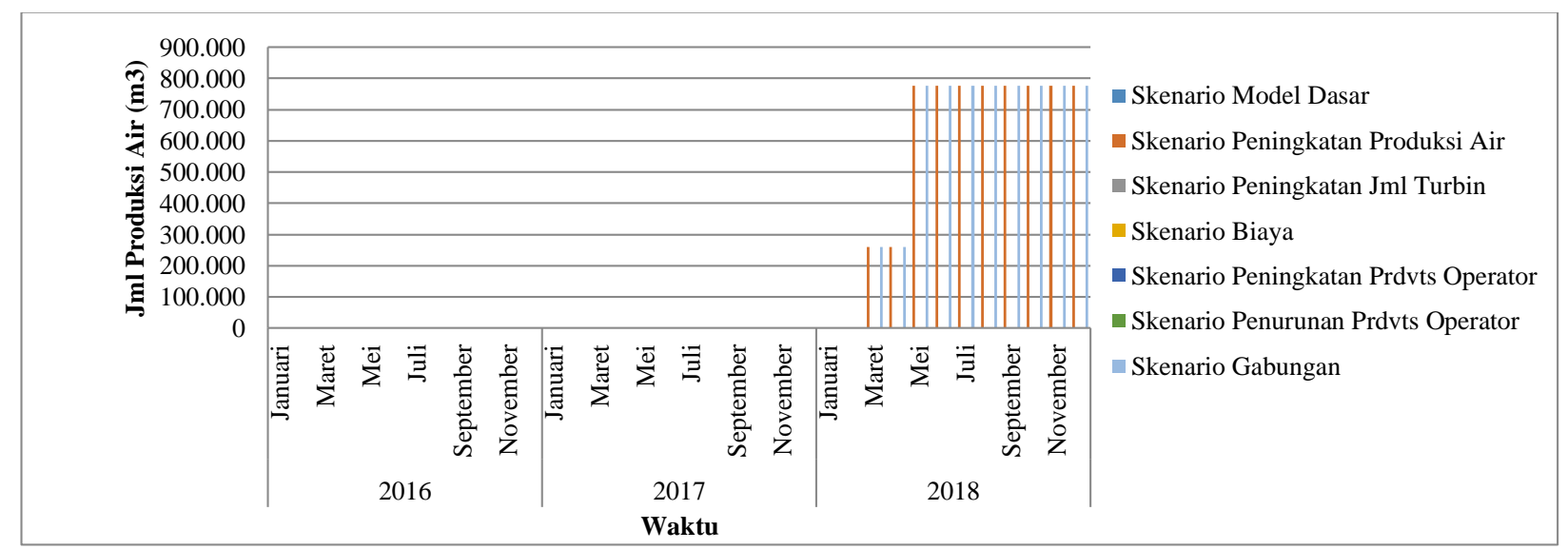

Gambar 5. Grafik Perbandingan Produksi Air dari Ketujuh Skenario

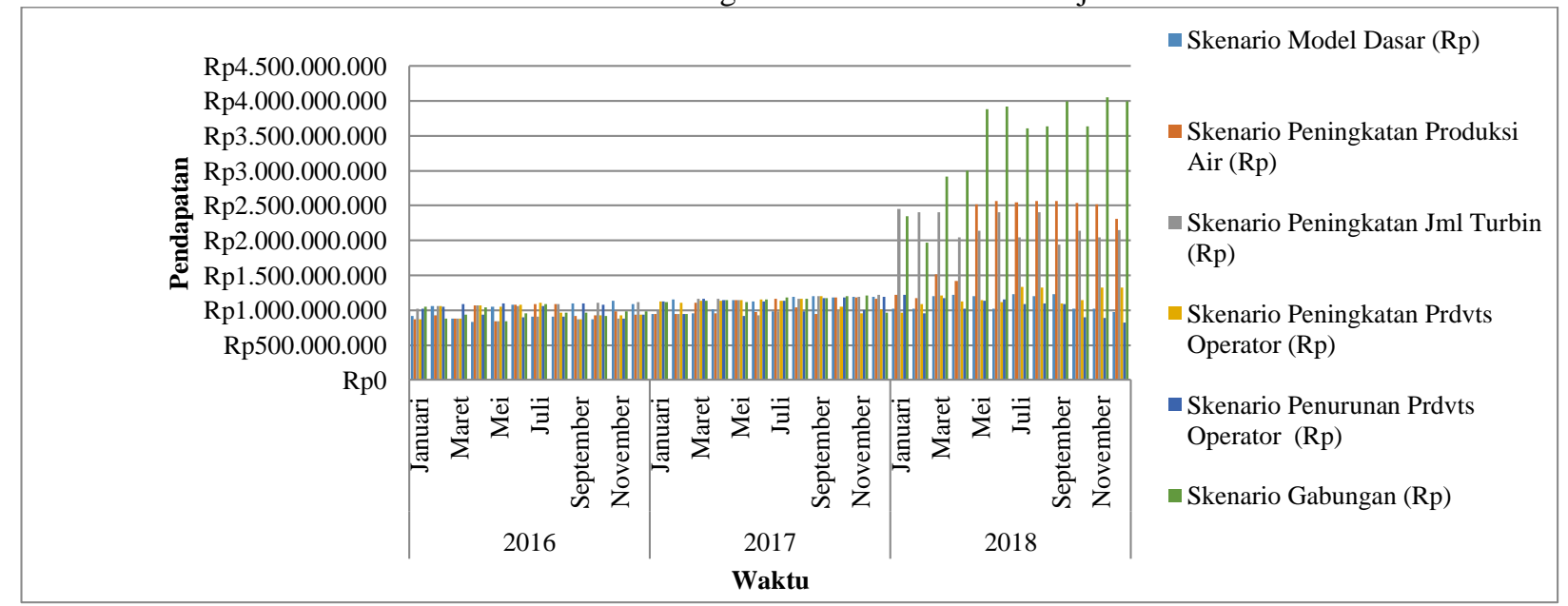

Gambar 6. Grafik Perbandingan Pendapatan dari Ketujuh Skenario 


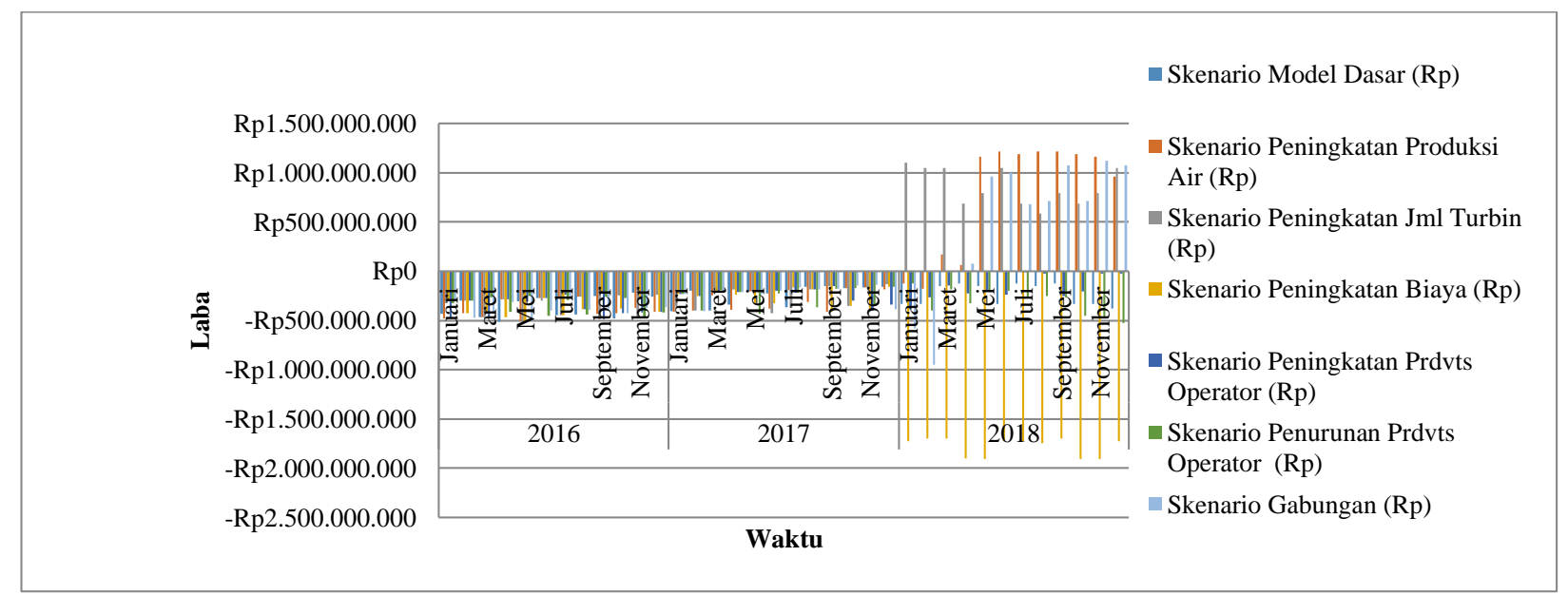

Gambar 7. Grafik Perbandingan Laba dari Ketujuh Skenario

Disamping itu, produksi listrik pun perlu ditingkatkan dengan meningkatkan faktor-faktor yang dapat mempengaruhi produksi listrik. Pertama, jumlah turbin dalam memproduksi air perlu ditambah sebesar $100 \%$, dari 4 unit menjadi 8 unit. Kedua, dengan meningkatkan produktivitas operatornya sebesar $22,2 \%$. Peningkatan produktivitas operator dapat dilakukan dengan meningkatkan kepuasan karyawan dan jumlah karyawan mengikuti training. Kepuasan karyawan harus meningkat sebesar 25,69\% dari yang sebelumnya tidak ada peningkatan sama sekali. Disamping itu dapat juga dengan cara meningkatkan jumlah karyawan yang mengikuti training dari $20-25$ orang menjadi $30-35$ orang agar karyawan yang terlatih semakin banyak. Hasil simulasi menunjukan bahwa terdapat pengaruh dari produktivitas operator yang cukup besar terhadap produksi listrik sehingga produktivitas operator pun perlu diperhatikan untuk meningkatkan pendapatan dan laba perusahaan. Oleh karena itu, perusahaan perlu juga meningkatkan Sumber Daya Manusia (SDM).

\section{Daftar Pustaka}

Akkermans, H., \& Van Oorschot, K. (2002). Developing a balanced scorecard with system dynamics. Journal of the operational research society, Vol. 54, hal 507514.

Barnabè, F. (2010). A "System Dynamics-based Balanced Scorecard" to Support Strategic Decision Making: Insight from a case study. International Journal of Productivity and Performance Measurement, Vol. 60, No.5, hlm. 446 - 473.

Cooper, D. R., \& Schindler, P. S. (2014). Business Research Methods (12 ed.). New York: McGrawHill/Irwin.

Davidsen, P. I. (2000). Issues in the design and use of system-dynamics-based interactive learning environments. Simulation \& Gaming, Vol.31, No.2, hal. 170-177.
Forrester, J. W. (2007). System Dynamics : A Personal View of The First Fifty Years. System Dynamics Review, Vol.23, No.2-3, hal.345-358.

Hajiheydari, N., Khakbaz, S. B., \& Ojaki, A. A. (2014). Developing responsive marketing system concept: Applying system dynamics approach. Science Journal of Business and Management, Vol.2, No.3, hal.91-96.

Simamora, B. (2003). Penilaian Kinerja dalam Manajemen Perusahaan. Jakarta: Gramedia Pustaka.

Moerdiyanto. (2010). Tingkat Pendidikan Manajer dan Kinerja Perusahaan Go - Public. Yogyakarta: Universitas Negeri Yogyakarta.

Sterman, J. D. (2000). Business Dynamics: System Thinking and Modeling for a Complex World. Working Paper Series. MIT Sloan School of Management.

Tangen, S. (2004). Performance measurement: from philosophy to practice. International journal of productivity and performance management, Vol.53, No.8, hal. 726-737.

Zhang T. (2012) An Overview of Dynamic Balanced Scorecard. Dalam: Deng W. (eds) Future Control and Automation. Lecture Notes in Electrical Engineering, vol 173. Springer, Berlin, Heidelberg.

Shaik, M. N., \& Abdul-Kader, W. (2013). Transportation in reverse logistics enterprise: A comprehensive performance measurement methodology. Production Planning \& Control, Vol. 24, No.6, hal. 495-510.

Kaplan, R. S., \& Norton, D. P. (2008). The execution premium: Linking strategy to operations for competitive advantage. Boston, MA: Harvard Business Press.

Mulyadi. 2001. Balanced Scorecard. Jakarta: Salemba Empat

Norreklit, H. (2000). The balance on the balanced scorecard a critical analysis of some of its assumptions. Management accounting research, Vol.11, No.1, hal. 65-88. 